\title{
Monitoring Perubahan Penggunaan Lahan Menggunakan Citra SPOT 6 dan SPOT 7 di Kota Semarang
}

\author{
Anisa Dalilah ${ }^{1 *}$, Alviana Ratna Malinda ${ }^{1}$, Recky Oktapiyansyah ${ }^{1}$, Windha Monica ${ }^{1}$, Fajar \\ Purnama $^{1}$
}

${ }^{1}$ Universitas Pendidikan Indonesia, Indonesia

\author{
A R T I C L E I N F O \\ Article history: \\ Received 11 Januari 2020 \\ Accepted 12 Juni 2021 \\ Available online 30 Juni \\ 2021 \\ Kata Kunci: \\ Perubahan Penggunaan \\ Lahan; Survey Lapangan; \\ Kota Semarang \\ Keywords: \\ Land Use Change; Ground \\ Check; Semarang City
}

\begin{abstract}
A B S T R A K
Perubahan penggunaan lahan terjadi di beberapa kota besar salah satunya adalah kota Semarang. Perubahan penggunaan lahan yang terjadi tentunya dapat memberikan perubahan nilai ekonomis lahan, namun apabila tidak dilakukan pengelolaan dengan baik, pada waktu yang akan datang dapat mengakibatkan degradasi nilai ekonomis lahan. Penelitian ini bertujuan untuk mengetahui perubahan penggunaan lahan di kota Semarang serta untuk mengetahui faktorfaktor yang mempengaruhi perubahan penggunaan lahan. Metode yang digunakan yaitu analisis citra multitemporal, menggunakan citra Spot 6 dan Spot 7 Pada citra 2013 dan citra 2019 untuk mengetahui perubahan penggunaan lahan. Hasil yang diproleh yaitu Peta perubahan penggunaan lahan yang telah diuji akurasi dengan cara Ground chek ke lapangan, akurasi data yang didapatkan kira kira 50\% dari hasil survey ke lapangan sebagian besar yang telah dilakukan terdapat perubahan penggunaan lahan di titik sampel yang telah ditentukan seperti hutan berubah menjadi lahan terbuka hijau dan lahan terbangun sedangkan area tambak berubah menjadi area persawahan.
\end{abstract}

\section{A B S T R A C T}

Land use changes occur in several major cities, one of which is the city of Semarang. Changes in land use that occur can certainly provide a change in the economic value of land, but if not carried out properly management, in the future it can lead to degradation of the economic value of land. This study aims to determine changes in land use in the city of Semarang and to find out the factors that influence land use change. The method used is multitemporal image analysis, using Spot 6 and Spot 7 images in 2013 and 2019 images to determine land use change. The results obtained are land use change maps that have been tested for accuracy by means of a ground check to the field, the accuracy of the data obtained is approximately $50 \%$ of the survey results to the field, most of which have been carried out there are changes in land use at predetermined sample points such as changing forests it becomes green open land and the land is built while the pond area is turned into a rice field area. 


\section{Pendahuluan}

Pertumbuhan penduduk yang sangat pesat serta bertambahnya tuntutan kebutuhan masyarakat akan lahan, seringkali mengakibatkan terjadinya ketidaksesuaian antara penggunaan lahan dan peruntukannya (Triagus 2012). Pertambahan jumlah penduduk kota juga berarti peningkatan kebutuhan akan lahan. Karena lahan tidak dapat bertambah, maka terjadilah perubahan penggunaan lahan yang cenderung menurunkan proporsi lahan-lahan yang sebelumnya. Seperti contoh kasus perubahan penggunaan lahan pertanian menjai lahan non pertanian. (Kusrini, 2011). Lahan merupakan suatu daerah dipermukaan bumi dengan sifatsifat tertentu yang meliputi biosfer, atmosfer, tanah, lapisan geologi, hidrologi, populasi tanaman, binatang dan hasil kegiatan manusia masa lampau dan masa sekarang. Sifat-sifat tersebut mempunyai pengaruh yang berarti terhadap penggunaan lahan oleh manusia pada zaman sekatrang dan masa yang akan dating (Kusrini, 2011). Di Indonesia, perubahan penggunaan lahan juga terjadi di beberapa kota besar salah satunya adalah kota Semarang. Perubahan penggunaan lahan yang terjadi tentunya dapat memberikan perubahan nilai ekonomis lahan, dan apabila tidak dilakukan pengelolaan dengan baik, pada waktu yang akan datang dapat mengakibatkan degradasi nilai ekonomis lahan.

Kota semarang adalah kota yang terdiri dari dua dataran yang membagi wilayah utama yaitu bagian utara yang merupakan dataran rendah yang dikenal dengan sebutan kota bawah dan bagian selatan merupakan dataran tinggi yang juga dikenal dengan sebutan kota atas. Daerah datarn rendah hanya berjarak sekitar 4 kilometer dari garis pantai sehingga menjadikan Kawasan tersebut seringkali terkena banjir yang disebabkan oleh luapan air laut ataau yang bias disebut banjir rob. Di bagian selatan merupakan dataran tinggi, telah mengalami perkembangan yang sangat pesat dengan munculnya Kawasan industri, jasa, serta permukiman.

Perkembangan kota membutuhkn lahan sebgai tempat hidup penduduk serta sebagai tempat untuk beraktivitas. Dengan demikian, sangatlah jelas bahwa setiap makhluk hidup pasti membutuhkan lahan untuk tumbuh dan berkembang, berbagai aktivitas manusia didalam ruang bumi tidak terlepas dari fungsi lahn yang berbeda-beda dalam penggunaan lahan. Penggunaan lahan adalah segala campur tangan manusia, baik secara menetap ataupun berpindah pindah terhadap suatu kelompok sumberdaya alam Maupun sumberdaya buatan, yang secara keseluruhan disebut lahan. Berbagai fenomena perubahan penggunaan lahan telah terjadi dari waktu ke waktu. Perubahan penggunaan lahan yang terjadi seiring dengan semakin meningkatnya pertambahan jumlah penduduk yang secara langsung berdampak pada kebutuhan terhadap lahan yang semakin meningkat.

Perubahan penggunaan lahan di Kota Semarang merupakan salah satu fenomena perubahan suatu wilayah akibat campur tangan manusia. Fenomena perunahan penggunaan lahan, dapat ikaji secara langsung maupun tidak langsung. Mealui penginderaan jauh kajian secara tidak langsung perubahan penggunaan lahan dapat dilakukan dengan lebih efisien dari segi waktu, maupun biaya. Identifikasi morfologi kota dapat dilakukan dengan memanfaatkan penginderaan jauh untuk menemukan trend arah perkembangan dan pembangunan wilayah yang berdasarkan kondisi penggunaan lahan dalam waktu tetentu yang dapat disajikan dalam peta sehingga dapat dibandingkan. Analisis multitemporal dengan data penginderaan jauh dapat membantu dalam pemantauan secara terus menerus dari perkembangan kota sehingga dapat dapat digunakan untuk keperluan prediksi perkembangan lahan. Interpretasi citra dilakukan dengan melihat karakteristik dasar kenampakan masingmasing penggunaan/penutupan lahan pada citra yang dibantu dengan unsur-unsur interpretasi.

Lahan adalah suatu lingkungan fisik yang meliputi tanah, iklim, relief, hidrologi, dan vegetasi dimana faktor- faktor tersebut mempengaruhi potensi penggunaannya. Termasuk didalamnya adalah akibat-akibat kegiatan manusia, baik pada masa lalu maupun sekarang (Hardjowigeno et al. 1993). Land-cover change dan land-use change memiliki arti yang berbeda. Landcover change diartikan sebagai perubahan fisik dan biologis penutupan tanah oleh vegetasi termasuk air. Pengamatan terhadap land-cover change biasanya dilakukan dengan remote sensing. Sedangkan land-use change memiliki arti yang lebih kompleks karena menyangkut juga 
perspektif alam (natural) dan sosial ekonomi terhadap perubahan penggunaan lahan atas aktivitas manusia yang berdampak terhadap perubahan proses yang terjadi di permukaan bumi termasuk biogeokimia, hidrologi dan keanekaragaman hayati. Dinamika perubahan penggunaan lahan seringkali menyebabkan perubahan kualitas lahan termasuk sumber daya air dikarenakan ketidaksesuaian antara kemampuan lahan dan penggunaannya. Pengamatan terhadap land-use change melibatkan pengamatan dan pengkajian langsung di lokasi.

Pengalih fungsian lahan dapat diartikan sebagai perubahan penggunaan lahan, perubahan penggunaan lahan tidak bisa dihindari dalam proses pembangunan (Lisdiyono, 2004). Dengan bertambahnya pertumbuhan penduduk yang sangat pesat dan juga bertambahnya tuntutan kebutuhan warga masyarakat akan lahan itu sendiri, seringkali terjadi bentrok pendapat untuk kepentingan yang macem macem, ketidaksesuaian lahan untuk rencana peruntukannya (Khadiyanto, 2005). Akan tetapi lahan itu bersifat terbatas tidak bisa bertambah kecuali dengan adanya kegiatan reklamasi (Sujarto, 1985 dalam Untoro, 2006). Berkembang pesatnya lahan di perkotaan menyebabkan pindahnya penggunaan lahan ke pinggiran kota. Dilihat dari penggunaan lahannya, wilayah pinggiran banyak sekali tingkat penggunaan lahannya yang asalnya wilayah pertanian beralih fungsi menjadi wilayah pemukiman atau lain sebagainya karena pertambahan penduduk yang sangat pesat dan juga pengaruh dari perkembangan kota di dekatnya yang sangat pesat (Rahayu, 2009). Dengan menurunya luas wilayah pertanian harusnya menjadi wilayh perhatian yang khusus supaya tidak terjadi penurunan yang signifikan karena berakibat pada wilayah desa sekitarnya dan juga wilayah perkotaan, karena dilihat dari kota kota sebalumnya membawa dampak yang sangat besar yang mengakibatkan perubahan penggunaan lahan yang sangat meningkat yang akan menjadi kota sepenuhnya di masa yang akan datang maka dari itu perlu kebijakan untuk menata dan mengelola wilayah tersebut supaya ideal sesuai dengan konsep rancangan kota untuk selanjutnya (Yunus, 2008).

Identifikasi morfologi kota dapat dilakukan dengan memanfaatkan penginderaan jauh untuk menemukan trend arah perkembangan dan pembangunan wilayah yang berdasarkan kondisi penggunaan lahan dalam waktu tetentu yang dapat disajikan dalam peta sehingga dapat dibandingkan Penginderaan jauh adalah ilmu atau seni untuk memperoleh informasi tentang objek, daerah atau gejala, dengan jalan menganalisis data yang diperoleh dengan menggunakan alat, tanpa kontak langsung dengan objek, daerah atau gejala yang akan dikaji. Perkembangan perkotaan yang sering terjadi adalah perkembangan lahan terbangun akibat proses ekspansi yakni perubahan tutupan lahan non terbangun menjadi lahan terbangun. Proses ekspansi tersebut dapat berdampak pada hilangnya lahan yang memiliki fungsi lindung, budidaya, ekologis sehingga dapat mengakibatkan permasalahan lingkungan.

Satelit penginderaan jauh dalam bidang kehutanan telah dikembangkan lebih dari 25 tahun, sedangkan perkembangan fotografi udara lebih dari 100 tahun. Penerapan satelit pengindraan jauh dalam bidang kehutanan secara efektif dimulai dengan peluncuran satelit sumber daya bumi Amerika Serikat (earth resources technological satellite/ERTS-1) pada tahun 1972, kemudian satelit tersebut diberi nama Landsat. Berdasarkan resolusi yang digunakan, citra hasil penginderaan jarak jauh bisa dibedakan atas (Thoha, 2008): a. Resolusi spasial Merupakan ukuran terkecil dari suatu bentuk (feature) permukaan bumi yang bisa dibedakan dengan bentuk permukaan disekitarnya, atau sesuatu yang ukurannya bisa ditentukan. Kemampuan ini memungkinkan kita untuk mengidentifikasi (recognize) dan menganalisis suatu objek di bumi selain mendeteksi (detectable) keberadaannya. b. Resolusi spektral Merupakan dimensi dan jumlah daerah panjang gelombang yang sensitif terhadap sensor c. Resolusi radiometrik Merupakan ukuran sensitifitas sensor untuk membedakan aliran radiasi (radiation flux) yang dipantulkan atau diemisikan suatu objek oleh permukaan bumi. d. Resolusi Temporal Merupakan frekuensi suatu sistem sensor merekam suatu areal yang sama (revisit). Seperti Landsat TM yang mempunyai ulangan setiap 16 hari, SPOT 26 hari dan lain sebagainya

Penginderaan jauh atau inderaja (remote sensing) adalah seni dan ilmu untuk mendapatkan informasi tentang obyek, area atau fenomena melalui analisa terhadap data yang diperoleh dengan menggunakan alat tanpa kontak langsung dengan obyek, daerah ataupun fenomena yang dikaji. Alat yang dimaksud dalam pengertian diatas adalah alat pengindera atau 
sensor. Pada umumnya sensor dibawa oleh wahana baik berupa pesawat, balon udara, satelit maupun jenis wahana yang lainnya (Sutanto,1986). Perkembangan penginderaan jauh ini semakin cepat seiring dengan kemajuan teknologi dirgantara. Sebelumnya penginderaan jauh lebih banyak menggunakan pesawat udara dan balon udara dalam perekaman data permukaan bumi, tetapi seiring dengan perkembangan penerbangan antariksa dan penggunaan satelit untuk berbagai kepentingan termasuk didalamnya perekaman permukaan bumi, maka penginderaan jauh tumbuh berkembang semakin cepat. Kini penginderaan jauh dapat digunakan dalam berbagai kebutuhan seperti kebutuhan untuk menganalisis perubahan penggunaan lahan. Analisis multitemporal dengan data penginderaan jauh dapat membantu dalam pemantauan secara terus menerus dari perkembangan kota sehingga dapat dapat digunakan untuk keperluan prediksi perkembangan lahan. Interpretasi citra dilakukan dengan melihat karakteristik dasar kenampakan masingmasing penggunaan/penutupan lahan pada citra yang dibantu dengan unsur-unsur interpretasi. Penelitian ini bertujuan untuk mengetahui perubahan penggunaan lahan yang terjadi di Kota semarang serta mengetahui factor apa saja yang mengakibatkan terjadinya perubahan penggunaan lahan di Kota Semarang.

\section{Metode}

Penelitian dilakukan di Kota Semarang, Jawa Timur. Yang luasnya sekitar 373,8 km2. Kota semarang merupakan kota yang kompleks dari berbagai segi permasalahan dari mulai letak geografisnya, kondisi topografi, dan lain sebagainya. Metode yang kami gunakan menggunakan metode analisis citra multitemporal, menggunakan citra Spot 6 dan cirta Spot 7 Pada citra 2013 dan citra 2019 untuk membedakan penggunaan lahannya. alat dan bahan yang digunakan pada penelitian kali ini adalah citra spot 6, citra spot 7, Software Arcgis, Softwar Envi, GPS, Kamera dan laptop. Ada beberapa tahapan metode untuk menghasilkan data peta analisis perubahan penggunaan lahan dan peta penutup lahan, yang pertama dilakukan yaitu koreksi geometrik pada citra 2013 dan citra 2019 berpacu pada Ground Contor Point. Kedua mengklasifikasi penggunaan lahan pada citra 2013 dan citra 2019. Ketiga mengoverlay data citra 2013 dan citra 2019. Ke empat membuat titik sample di data yang telah di overlay untuk di ground chek ke lapangan untuk akurasi datanya. Kelima setelah ground chek ke lapangan dilakukan rekapitulasi data. Keenam pengolahan data sampai menghasilkan data perubahan penggunaan lahan.

Metode yang digunakan pada tahapan koreksi geometrik yaitu supaya data citra bisa di proyeksikan sesuai dengan system koordinat yang dipakai, Dengan cara memberikan titik ikat ground control point yang telah diketahui koordinatnya pada citra yang tidak ada koordinatnya pada lokasi yang sama. Uji akurasi sangat dibutuhkan pada penelitian kali ini menggunakan Independent Check Point [ICP]. Independent Check Point diperlukan untuk menguji akurasi yang telah dilakukan menggunakan Ground Control Point. (Saraswati, 2015).

Klasifikasi citra diperlukan pada metode kali ini, klasifikasi citra mempunyai dua tahapan utama untuk proses pengolahan klasifikasi berbasis objek yaitu proses segementasi dan klasifikasi. Mempunyai 3 parameter pada proses segmentasi multiresolusi yaitu bentuk, kekompakan dan skala. Hasil dari segmentasi membentuk segmen segmen pada citra. Setelah segmen berupa objek yang lanjut akan di klasifikasikan. Klasifikasi bertujuan untuk mengelompokan jenis penggunaan lahan yang ada di citra tersebut sesuai dengan karakteristik kelas penggunaan lahannya.

Overlay data citra yang telah di koreksi geometric dan telah klasifikasi citra pada kedua citra tersebut bertujuan untuk menyatukan data citra 2013 dan citra 2019 supaya lebih terlihat perubahan penggunaan lahan pada data citranya.

Pembuatan titik sample pada citra yang telah di overlay bertujuan untuk mengambil sample data dilapangan untuk menguji akurasi data lapangan supaya berpatok pada koordinat yang telah di ketahui, berikut persebaran titik sample yang telah kami buat sebelum Ground Check ke lapangan seperti terlihat pada Gambar 1. 


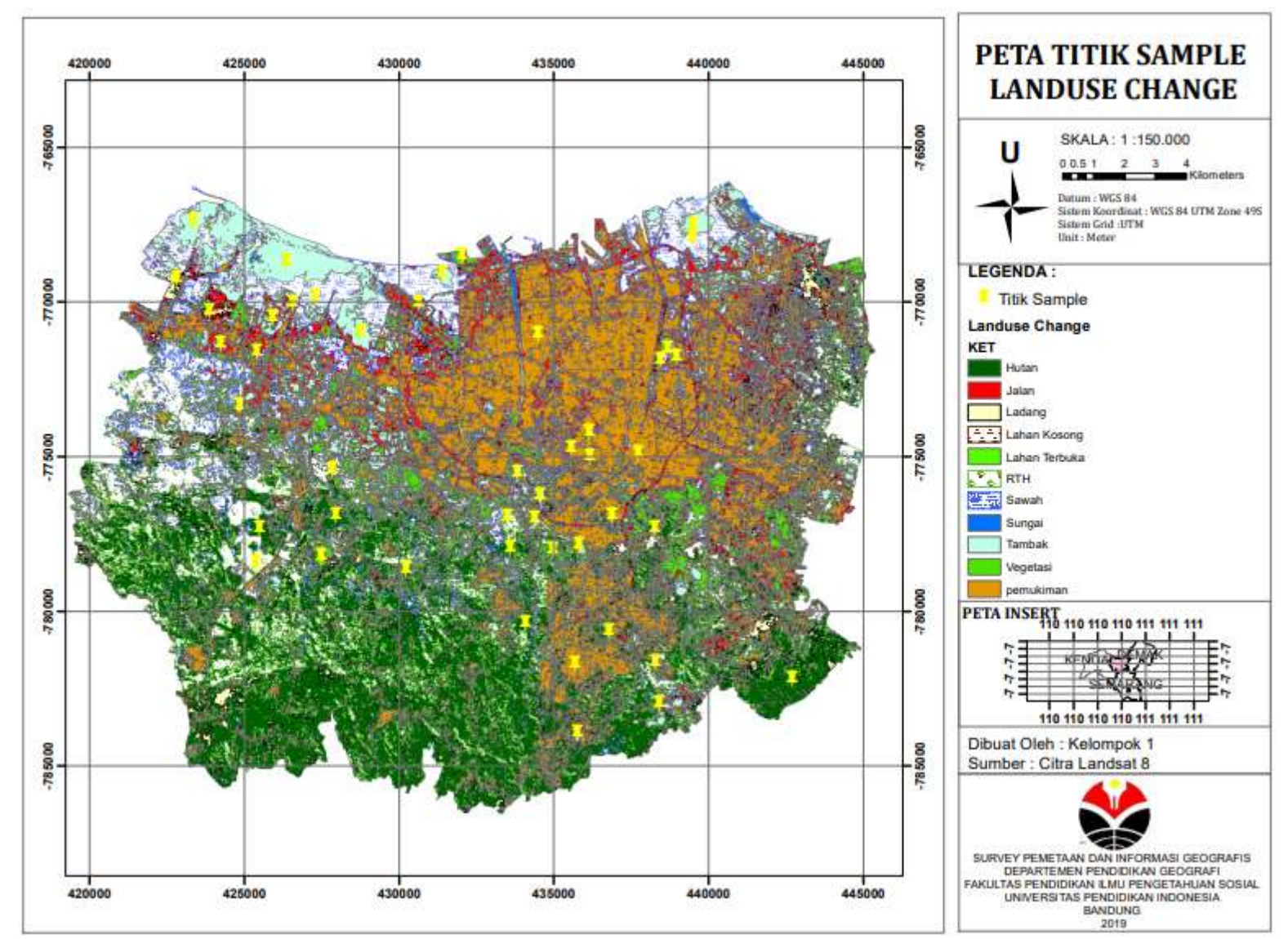

Gambar 1. Peta Persebaran Titik Sample Landuse Change Kota Semarang Provinsi Jawa Tengah

Ground chek atau survey lapangan untuk mengetahui kondisi dilapangan itu seperti apa. Apakah datanya sesuai atau tidak supaya data yang dihasilkan lebih akurat kebenaran datanya Pengumpulan data hasil lapangan diperlukan untuk mempermudah pengolahan data citra, yang dilakukan di tahapan selanjutnya supaya data lengkap dan mencarinya lebih mudah pada saat pengolahan data. Pengolahan data citra hasil lapangan diolah sampai mengetahui perbedaan atau perbandingan penggunaan lahan di kota semarang dari hasil ground check.

\section{Hasil dan pembahasan}

\section{Analisis Perubahan Penggunaan Lahan Kota Semarang}

Analisis perubahan penggunaan lahan dilakukan dengan membandingkan peta penggunaan lahan kota semarang hasil perekaman citra tahun 2013 dengan peta penggunaan lahan tahun 2019. Citra hasil pengolahan kemudian diinterpretasi sehingga diketahui penggunaan lahan yang terdapat di kota semarang. Setelah di interpretasi setiap penggunaan lahan kedua citra tersebut kemudian dilakukan penggabungan atau Overlay dari kedua peta tersebut. Hasil dari penggabungan tersebut didapat perubahan penggunaan lahan yaitu hutan berubah menjadi lahan terbuka hijau dan lahan terbangun sedangkan area tambak berubah menjadi area persawahan. Dari hasil anlisis tersebut dilakukan ploting titik semple yang kemudian dilakukan ground check. Berikut peta pengunaan lahan 2013 dan 2019 dari citra Spot 6 dan Spot 7 seperti terlihat pada Gambar 2 dan Gambar 3. 


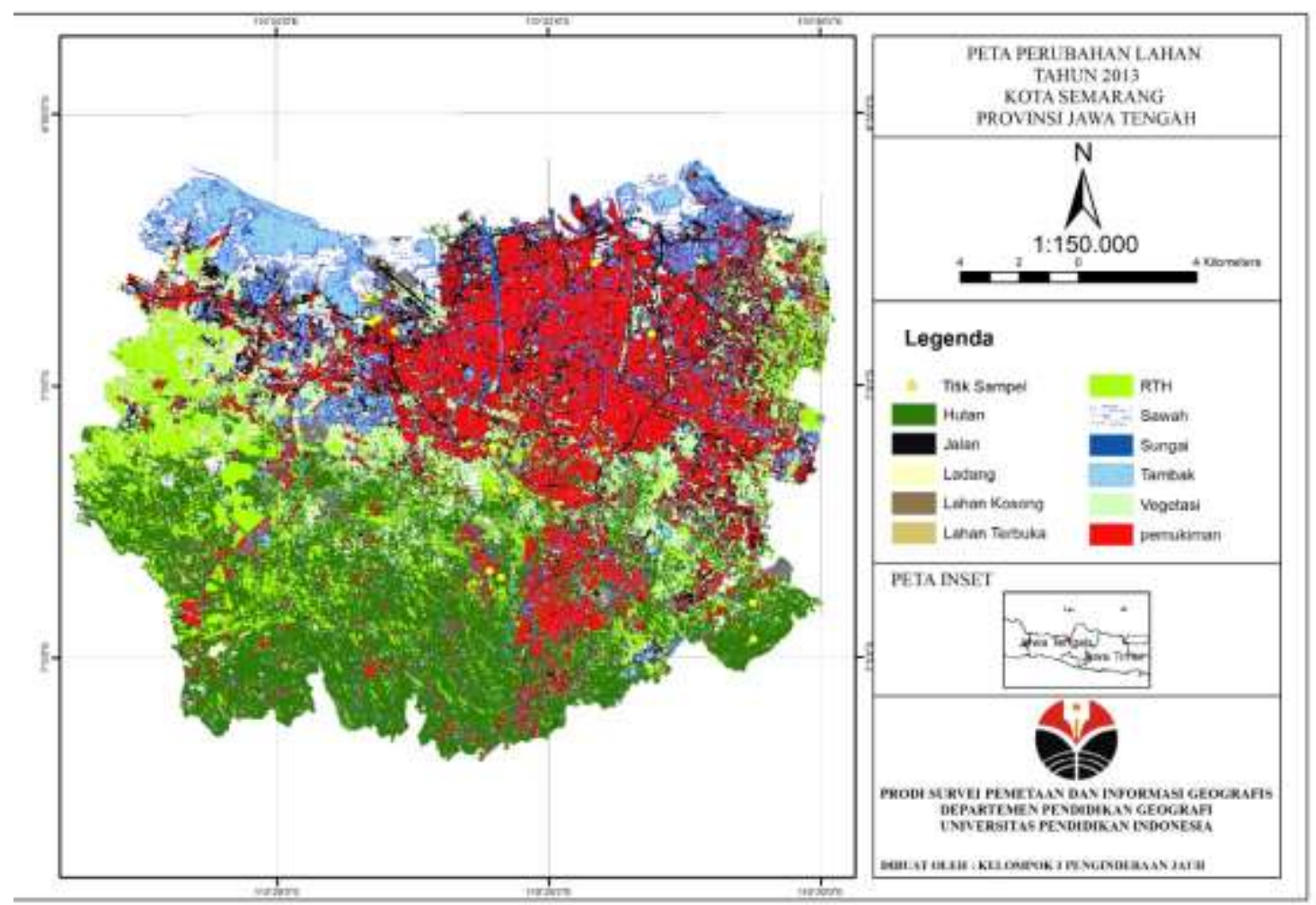

Gambar 2. Peta Penggunaan Lahan Tahun 2013 Kota Semarang Provinsi Jawa Tengah
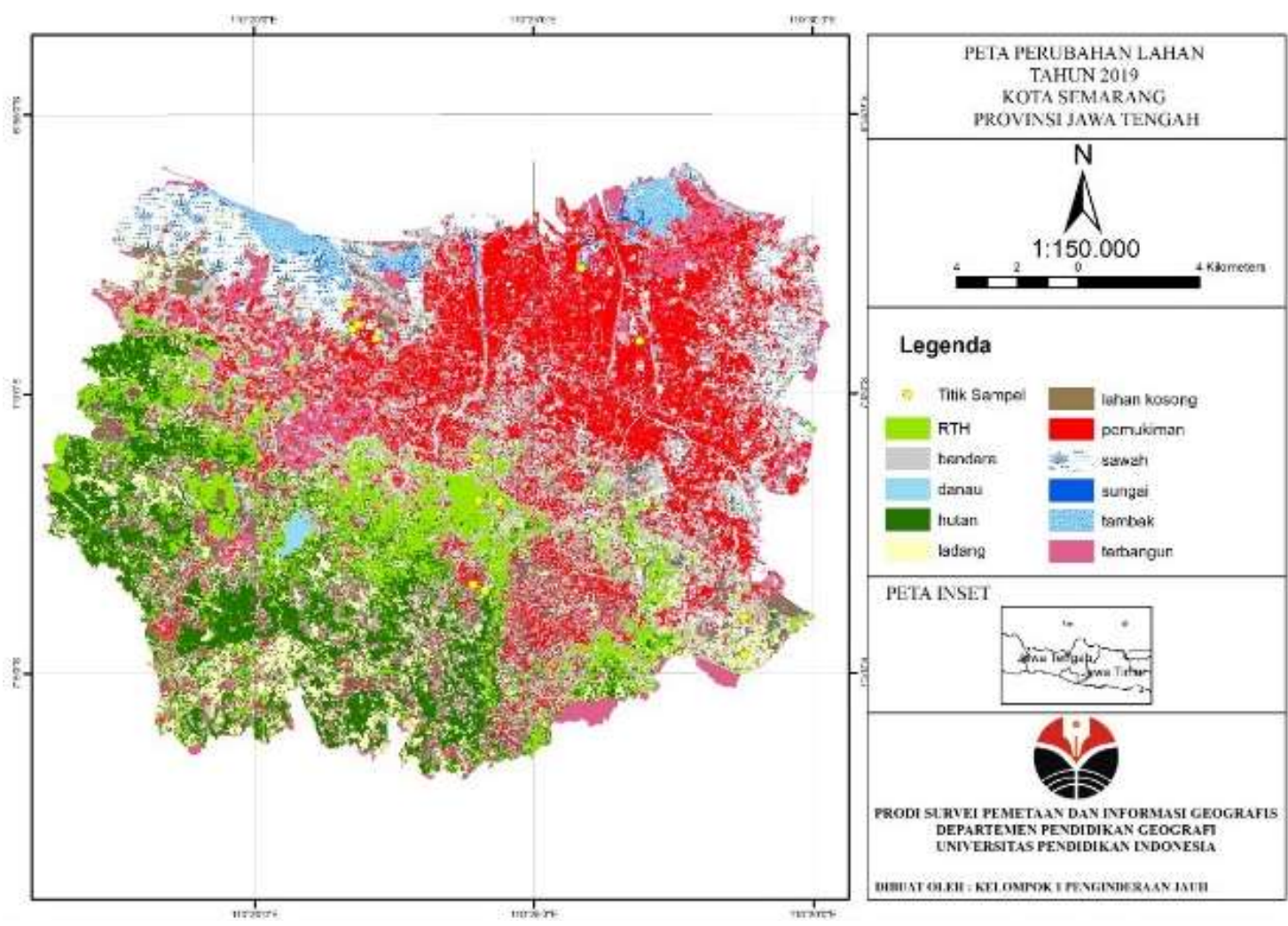

Gambar 3. Peta Penggunaan Lahan Tahun 2019 Kota Semarang Provinsi Jawa Tengah 

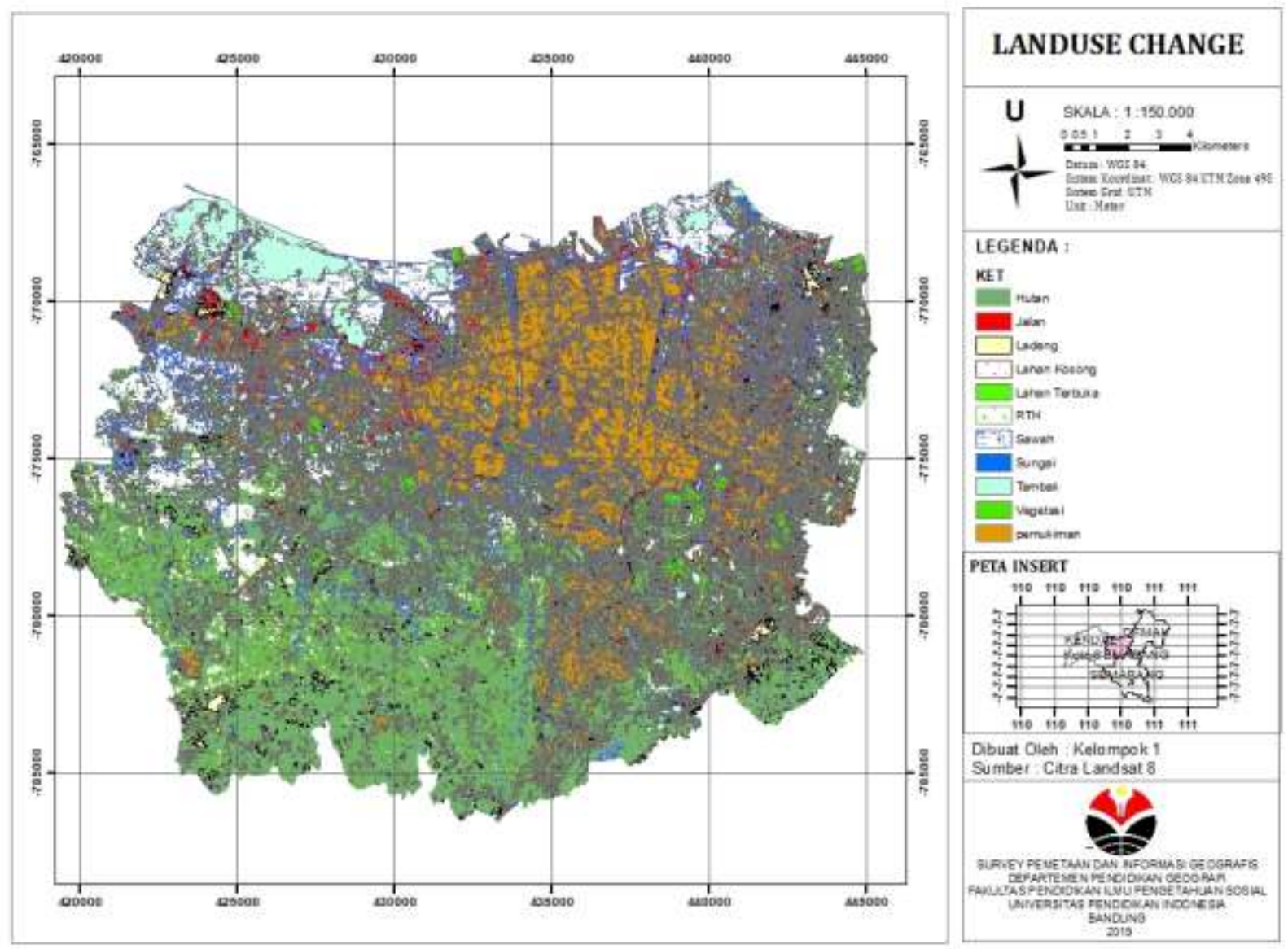

\section{Gambar 4.}

Overlay Peta Penggunaan Lahan Tahun 2013 dan 2019 Kota Semarang Provinsi Jawa Tengah

\section{Uji Akurasi Perubahan Penggunaan Lahan}

Dari penelitian uji akurasi lapanagan didapat penggunaan lahan yang tidak sesuai dengan hasil interpretasi citra yaitu area persawahan. Pada citra terdapat 4 titik area persawahan namun setelah ground check ke empat titik tersebut merupakan area tambak. Untuk penggunaan lahan berupa pemukiman interpretasi di citra didapat 2 titik namun area tersebut bertambah. Berikut tabel uji akurasi hasil ground check dari lapangan seperti terlihat pada Tabel 1.

Tabel 1.

Hasil Interpretasi Data Pengolahan Penggunaan Lahan Tahun 2019 Kota Semarang Provinsi Jawa Tengah

\begin{tabular}{|c|c|c|c|c|c|c|c|c|c|c|c|}
\hline \multicolumn{12}{|c|}{ Hasil Interpertasi } \\
\hline \multirow{10}{*}{ Data pengelohan } & objek & Hutan & Ladang & Lahan Kosong & Lahan Terbuka & RTH & Sawah & Tambak & Vegetasi & Pemukiman & jumlah \\
\hline & Hutan & 2 & & & & & & & & & 2 \\
\hline & Ladang & & 1 & & & & & & & & 1 \\
\hline & Lahan Kosong & & & 4 & & & & & & & 4 \\
\hline & Lahan Terbuka & & & & & & & & & & \\
\hline & RTH & & & & & & & & & & \\
\hline & Sawah & & & & & & 4 & & & & 4 \\
\hline & Tambak & & & & & & & 1 & & & 1 \\
\hline & Vegetasi & & & & & & & & & & \\
\hline & Pemukiman & & & & & & & & & 2 & 2 \\
\hline jumlah & & & & & & & & & & & 14 \\
\hline
\end{tabular}


Tabel 2.

Hasil Interpretasi data lapangan Penggunaan Lahan Tahun 2019 Kota Semarang Provinsi Jawa Tengah

\begin{tabular}{|c|c|c|c|c|c|c|c|c|c|c|c|}
\hline \multicolumn{12}{|c|}{ Hasil Interpertasi } \\
\hline \multirow{10}{*}{ Data Lapangan } & objek & Hutan & Ladang & Lahan Kosong & Lahan Terbuka & RTH & Sawah & Tambak & Vegetasi & Pemukiman & jumlah \\
\hline & Hutan & 2 & & & & & & & & & 2 \\
\hline & Ladang & & & & & & & & & & \\
\hline & Lahan Kosong & & & 2 & & & & & & & 2 \\
\hline & Lahan Terbuka & & & & 2 & & & & & & 2 \\
\hline & RTH & & & & & & & & & & \\
\hline & Sawah & & & & & & & & & & \\
\hline & Tambak & & & & & & & 3 & & & 3 \\
\hline & Vegetasi & & & & & & & & 2 & & 2 \\
\hline & Pemukiman & & & & & & & & & 3 & 3 \\
\hline nlat & & & & & & & & & & & 14 \\
\hline
\end{tabular}

Tabel 3. Kelas Penggunaan Lahan Tahun 2019 Kota Semarang Provinsi Jawa Tengah

\begin{tabular}{|c|c|c|c|c|}
\hline kelas & citra & lapangan & akurasi & \\
\hline hutan & 2 & 2 & 2 & \\
\hline ladang & 1 & & 0 & \\
\hline lahan kosong & 4 & 2 & 2 & \\
\hline lahan terbuka & & 2 & 0 & \\
\hline RTH & & & 0 & \\
\hline Sawah & 4 & & 0 & \\
\hline Tambak & 1 & 3 & 1 & \\
\hline Vegetasi & & 2 & 0 & \\
\hline Pemukiman & 2 & 3 & 2 & \\
\hline jumlah & 14 & 14 & 7 & $50 \%$ \\
\hline
\end{tabular}

Dari hasil ground chek lapangan dan data yang telah diolah dari citra 2013 dan citra 2019 akurasi datanya kira kira 50\%. Secara keseluruhan hasil uji akurasi di lapangan di dapat penggunaan lahan berupa 2 titik sempel hutan, 2 titik lahan kosong, 2 titik lahan terbuka, 3 tambak, 2 vegetasi, dan 3 titik pemukiman. Sedangkan hasil interpretasi perubahan penggunaan lahan dari citra adalah 4 titik sempel lahan kosong, tidak ada lahan terbuka, ada, sawah, dan tidak ada vegetasi. Dari perbandingan tersebut didapat hanya 7 titik sempel yang akurat dari total 14 titik sempel dan tingkat keakuratan sebesar 50\% yang berarti data dari hasil interpretasi kurang baik dan kurang akurat.

Berdasarkan hasil penelitian oleh salah satu mahasiswa pendidikan geografi IKIP Veteran Semarang yang berjudul Analisis Perubahan Penggunaan Lahan untuk Pemukiman dan Industri dengan menggunakan Sistem Iinformasi Geografis lokasi kajian kota semarang di dapat bahwa perubahan penggunaan lahan untuk pemukiman dan industry di kecamatan Genuk, kota semarang banyak terjadi pertambahan pemukiman di setiap kelurahan dalam kurun waktu 5 tahun dari tahun 2009-2013. Namun ada beberapa pemukiman dan industry yang hilang atau sudah tidak ada di tahun 2013 yang disebabkan oleh beberapa factor salah satunya akibat banjir rob atau masuknya air laut ke daratan.

Sama halnya dengan hasil penelitian tersebut hasil ground check di dapat pertambahan area pemukiman berbentuk perumahan yang dibangun di dekat dekat lahan yang cenderung kosong bahkan sampai mendekati area hutan. Sedangkan industri berupa pabrik. Hal yang paling menonjol adalah banyaknya area tambak di sepanjang pesisir pantai yang menjadi ciri khas daerah tersebut. Hal tersebut membuat praktikan sulit menginterpretasi, yang dikira area persawahan yang sangat luas ternyata setelah ground check ke lapangan berupa tmbak yang sangat luas.

Kota semarang menjadi salah satu kota metropolitan yang banyak melakukan pembangunan baik untuk pemukiman dan industri sehingga dinobatkan menjadi kota 
metropolitan ke 5 di Indonesia setelah Jakarta, Surabaya, Medan, dan Bandung. Dalam pembangunan, kota semarang telah banyak membangun bangunan- bangunan pencakar langit yang digunakan untuk pemukinan dan area perekonomian. Selain di pusat kota tak jarang di area dekat lading, lahan kosong, bahkan hutan dibangun pemukiman teratur atau perumahan. Hal tersebut didorong pula meningkatnya jumlah penduduk.

Ketika pemukiman semakin luas maka area lainnya akan menjadi sedikit hal tersebut karena luas lahan akan bersifat tetap yang membedakan aja jenis penggunaan lahan yang ada. Berbanding terbalik dengan jumlah penduduk yang semakin bertambah sehingga kebutuhan sandang, pangan, dan papan akan terus bertambah. Selain bertambahnya jumlah pemukiman hal lain yang bertambah adalah industri yang berfungsi sebagai mata pencaharian untuk bertahan hidup untuk memenuhi kebutuhan hidup. Penggunaan lahan yang tidak mengalami pengurangan adalah tambak karena tambak merupakan salah satu sumber mata pencaharian bagi masyarakat sekitar pesisir pantai.

\section{Simpulan dan saran}

Penelitian dilakukan di Kota Semarang, Jawa Tengah. Penelitian yang dilakukan terkait perubahan penggunaan lahan. Hasil yang diperoleh dari penelitian di kota semarang ada beberapa penggnaan lahan yang mengalami perubahan dari tahun 2013-2019 pada sample titik yang telah ditandai pada beberapa tempat di Kota Semarang. Hasil Ground check di lapangan terdapat penggunaan lahan yang berubah antara lain tambak, sawah, vegetasi, dan lahan terbuka. Hal yang paling menonjol dari perubahan penggunaan lahan ini adalah perubahan lahan terbuka dan hutan yang berubah menjadi pemukiman teratur (perumahan) sedangkan di daerah perkotaan banyak didirikan bangunan tinggi yang digunakan sebagai tempat bisnis maupun industri.

Saran untuk penelitian kedepannya adalah diperhatikan kembali interpretasi penggunaan lahan pada citra dan gunakan citra yang memiliki resolusi tinggi sehingga interpretasi memiliki keakuratan yang baik. Hal tersebut berpengaruh terhadap pengambilan titik sempel yang digunakan sebagai titik ground check di lapangan sehingga hasil uji akurasi mendapatkan hasil yang detail dan data dapat digunakan untuk kepentingan pemerintah dalam mengambil keputusan dalam pembuatan peraturan-peraturan terkait lingkungan hidup dan sebagainya.

\section{Daftar Rujukan}

Anggoro, A. (2015). Penginderaan Jauh dan Pengolahan Data Citra Digital. Jakarta: Lapan.

Arisondang, V. (2015). Klasifisasi Tutupan Lahan Menggunakan Metode Segmentasi Berbasis Algoritma Multiresolusi. Jurnal Geodesi Undip. 10(1), 1-10.

Eko, T. (2012). Perubahan Penggunaan Lahan dan Kesesuaiannya terhadap RDTR Wilayah PeriUrban. Planologi Undip.

Hardjowigeno, S. (1993). Klasifikasi Tanah dan Pedogenesis. Jakarta: Akademika, Pressindo.

Kusrini. (2011). Perubahan Penggunaan Lahan Jawa Tengah. Indonesia.

Pangestu, S. (2015). Analisis Citra Satelit Multitemporal untuk Deteksi Perubahan Penggunaan

Lahan dengan menggunakan Metode Post Classification Comparission di sebagian DKI Jakarta. Jurnal Geodesi Undip. 11(1), 1-10.

Mastuti, A. (2016). Kondisi Prospek Pengembangan Eksisting Ruang Terbuka Hijau Publik Di Kota Surakarta. Universitas Diponegoro. Semarang.

Pangestu. (2010). Analisis Citra Satelit Multi Temporal. Geografi UGM

Pigawati. (2011). Penggunaan Citra Satelit untuk Kajian Perkembangan Kawasan Pemukiman di Kota Semarang. Semarang: Universitas Muhammadiyah Surakarta.

Parman. (2010). Deteksi Perubahan Garis Pantai melalui citra Penginderaan Jauh di Pantai Utara Semarang Demak. Semarang: Universitas Negeri Semarang.

Purwanto, A. D. (2017). Identifikasi Mangrove Sejati Menggunakan Metode OBIA. Jakarta: Lapan.

Sukristianti. (2019). Evaluasi Indeks Urban pada citra Lansat Multitemporal dalam Ekstraksi Kepadatan Bangunan. Bandung: LIPI.

Sutanto. (1986). Penginderaan Jauh Jilid I. Yogyakarta: Gadjah Mada University Press.

Thoha, A. S. (2008). Karakteristik Citra Satelit. Universitas Sumatera Utara, Medan. 
Virma. (2013). Analisis Perubahan Kerapatan Vegetasi Kota Semarang Menggunakan Bantuan Teknologi Penginderaan Jauh. Semarang: Universitas Negeri Semarang.

Zahrotunisa, Siti. (2017). Predisksi Spasial Perkembangan Lahan Terbangun Melalui Pemanfaatan Citra Landsat Multitempotal Kota Bogor. Yogyakarta: Penerbit Andi. 